\title{
WAYS OF LOGISTICS IMPROVEMENT OF THE FREIGHT MARKET
}

\author{
(C)Gaffarov M., Andijan Institute of Mechanical Engineering, \\ Andijan, Uzbekistan, gaffarov1965@inbox.ru
}

\section{СПОСОБЫ УЛУЧШЕНИЯ ЛОГИСТИКИ ГРУЗОВОГО РЫНКА}

\section{(СГаффаров М. Т., Андижанский машиностроительный институт, г. Андижан, Узбекистан, gaffarov1965@inbox.ru}

Abstract. Problems in the freight transportation market are considered: low solvency of customers, increase in the vehicle fleet and increased competition in the market, determination of tariffs for the transportation of goods based on the state of customers on idle cars, setting bonus tariffs in the same direction. The calculations and the sequence of actions for creating transport logistics are presented.

Аннотация. Рассматриваются проблемы на рынке грузовых перевозок: низкая платежеспособность клиентов, увеличение автопарка и усиление конкуренции на рынке, определение тарифов на перевозку грузов исходя из состояния клиентов на простаивающих автомобилях, установление бонусных тарифов в том же направлении. Представлены расчеты и последовательность действий для создания логистики транспорта.

Keywords: transportation tariff, cost, solvency, bonus tariff, idle time.

Ключевые слова: транспортный тариф, стоимость, платежеспособность, бонусный тариф, простой.

Currently, there are a number of problems in the market: insufficient customer pay, increased car shed, idle hours waiting for the customer to increase the cost of transportation, and increasing the cost of transportation by self-service [1].

Developing a model for ensuring the freight and passenger suitability on the basis of these factors in the marketplace, developing carriers' activities, differentiating tariffs based on the solvency of the customer, prompt payment for the carriage, fixing tariffs for carriage, reducing car wait times. Increase the volume of freight, reduce the cost of transportation, and require the integration of each customer and carriers together. o enough. Implementation of these measures will ensure long-term development [2].

The low demand of the customer is the provision of the truck of any brand at any time. The demand of the auto company is to achieve a salary of $15-30 \%$, while upgrading their cars, to raise the salaries of the employees above the salaries of the budgeted businesses [3].

To achieve these two objectives, firstly, a contracted freight route will be established, a daily operating capacity of the route, a coefficient of road use is calculated, and transportation costs are calculated with the customer taking into account road conditions [4].

For example, on a contract basis: leg $=10, V_{\mathrm{t}}=24 \mathrm{~km} / \mathrm{h}, \mathrm{l}_{\mathrm{n} 1}=10 \mathrm{~km}, 1_{\mathrm{n} 2}=10 \mathrm{~km}, \mathrm{Q}=3066 \mathrm{t}$, $\mathrm{t}_{\mathrm{o}-\mathrm{t}}=0.5$ hours $\mathrm{D}_{\text {kun }}=30$ days $\beta_{\mathrm{e}}=0,52$ or $\xi=$ ? count. 
For backbone traffic with a revolving probe on this pendulum route, there is no back-to-back vehicles (Figure).

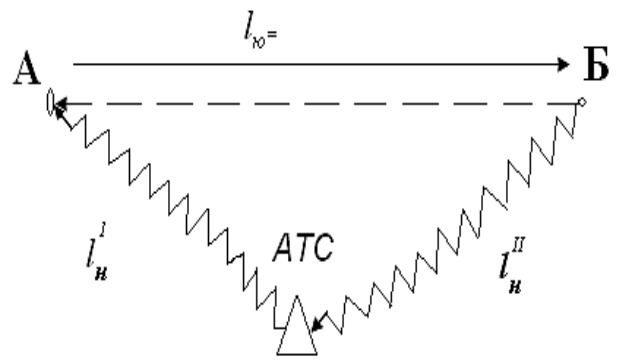

Figure. Route to the pendulum with no return

To calculate the work account, we calculate the following. Cargo distance $\ell_{10}=10 \mathrm{~km}-$, zero flights $\ell_{\mathrm{H} 1}=10 \mathrm{\kappa M}, \ell_{\mathrm{H} 2}=10 \mathrm{\kappa M}$, Cargo class 1 class grain $\left(\gamma_{\mathrm{cт}}=1\right)$. Total cargo load $Q=3066 \mathrm{t}$.

For 30 days the ZIL-130-76 car will be operated with the following parameters: $V_{T}=24 \mathrm{~km} / \mathrm{h}$, $\mathrm{t}_{\mathrm{o}-\mathrm{t}}=0.7$ hours, running time $\mathrm{Tn}=14$ hours, Ae, $\mathrm{L}_{\mathrm{kun}}$ and $\beta \mathrm{e}$ it is necessary to identify the.

Find the time when cars are on the route. In the same example, since $b m=0.5$ :

$\mathrm{m}=\mathrm{Tn}-$ to $=\mathrm{Tn}-(\ell \mathrm{n} 1+\ell \mathrm{n} 2) / \mathrm{W}=14-(4+8) / 24=13.5$ hours.

2. Number of daily flights:

$\mathrm{Zge}=\mathrm{Tn} * \mathrm{~b} * \mathrm{~W} /$ leg $+\mathrm{be} * \mathrm{~W} *$ to-t $=13.5 * 0.5 * 24 / 10+0.5 * 24 * 0.7=8.8 \sim 9$ (fold).

Number of flights $\mathrm{Zge}=9$ recalculate $\mathrm{Tm} 1$ as a whole:

$\mathrm{Tm} 1=\mathrm{Zge}(\ell$ eg + be $* \mathrm{~W} *$ to-t $) /$ be $* \mathrm{~W}=9(10+0.5 * 24) / 0.5 * 24=13.8$ hours Working time $\operatorname{Tn} 1=\operatorname{Tm} 1+$ to $=13,8+0.5=14.3$ hours.

3. Determine the daily labor productivity of the car: in tons

Qkun $=\mathrm{qn} *$ gst $* \mathrm{Zge}=6 * 1 * 9=54$ tonna.

Rkun $=\mathrm{qn} * \mathrm{gst} *$ leg $* \mathrm{Zge}=6 * 1 * 9 * 10=540 \mathrm{tkm}$

Number of vehicles required to complete the transportation plan:

$\mathrm{Ae}=$ Green $/$ Dick $*$ Kkun $=30660 / 30 * 54=19$ units.

4. Vehicle parking.

Lkun $=\ell$ eg $*$ Zge $/$ be $-\ell \mathrm{x}+(\ell \mathrm{n} 1+\ell \mathrm{n} 2)=10 * 9 / 0.5-10+(4+8)=182 \mathrm{~km}$

Daily distance coefficient:

be $=$ leg $*$ Zge $/$ Lsut $=10 * 9 / 182=0.495$

$\mathrm{x}$ denotes the path per car to the unit of work $\mathrm{x}=\mathrm{Lum} / \mathrm{Pkun}=182 / 540=0.337$

This deviation coefficient will be determined and based on which a specific rate will be determined and presented to the customer.

$\mathrm{D} 1=\mathrm{m} 1+\mathrm{X} 1+\mathrm{X} 2+\mathrm{X} 3+\mathrm{X} 4+\mathrm{X} 5+\mathrm{X} 6+\mathrm{X} 8+\mathrm{X} 9$

$\mathrm{m} 1$ - month - monthly social expenditures

$\mathrm{X} 1$ - fuel consumption

$\mathrm{X}$ - May costs

Preparation costs for the $\mathrm{X}$ equipment.

X - Spending

Expenditure on X-upgrade.

$\mathrm{X}$ Period Expenses.

$\mathrm{X}$ - gross profit.

$X$ - Road Fund and various contributions.

$X u=m 1+X 1+X 2+X 3+X 4+X 5 ; X m=X y+X 6+X 9 ;$

$\mathrm{Hm}$ - full cost.

Find the weight of incomplete cost in income. 


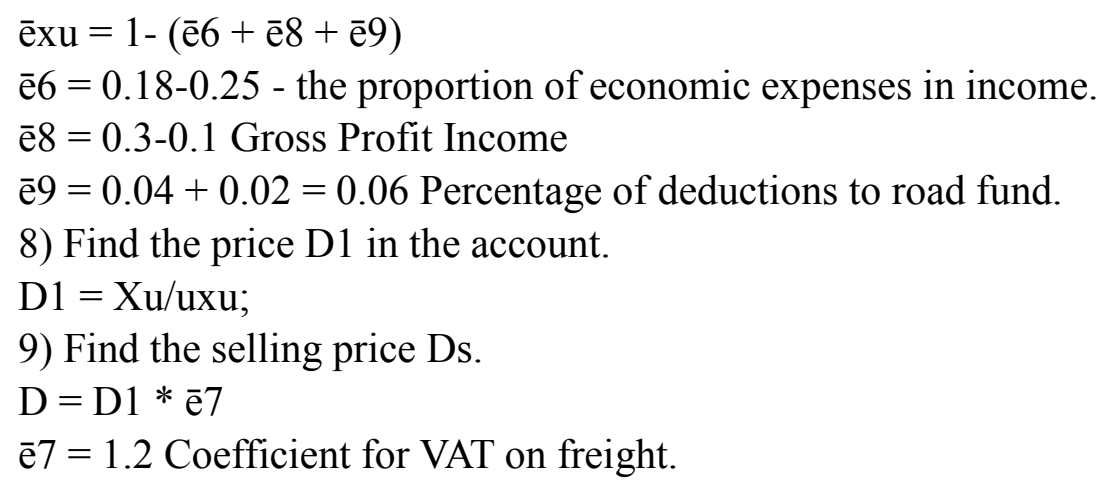

Taking into account all of the above mentioned costs and other parameters, the thresholds are calculated, and each car company will develop a contract plan based on its own transportation capacity. If you make a quick payment, you can offer bonus discounts [5-14]. This will integrate both carrier and customer requirements.

References:

1. Borisov, D. A. (2019). Uzbekistan's Foreign Policy under Sh. Mirziyoyev: Strategy and Practice. Izvestiya Ural'skogo federal'nogo universiteta. Seriya 3: obshchestvennye nauki, 14 (2(188)) 130-139. (in Russian).

2. Samatov, G. A., Kamildjanov, B. I., \& Galimova, F. G. (2015). Concept and model logisticheskogoupravleniya. Tashkent.

3. Butaev, Sh. A., Sidiknazarov, K. M., Murodov, A. S., \& Kuziev, A. U. (2012). Logistics. Tashkent.

4. Tretyakova, A. P., Zykov O. A. (2010). Logistics. Tyumen. (in Russian).

5. Gadzhinsky, A. M. (1999). Logistics. Moscow. (in Russian).

6. Levkin, G. G. (2009). Logistics: Theory and Practice. Rostov n/D. (in Russian).

7. Mirotin, L. B. (2002). Transportation logistics. Moscow. (in Russian).

8. Lukinsky, V. S. 2007. Model and Methodist Theory Logist. St. Petersburg. (in Russian).

9. Lavrikov, I. N., \& Penshin, N. V. 2016. Transportation logistics. Tyumen. (in Russian).

10. Dybskaya V. V., Zaitsev E. I., Sergeev V. I., Sterlikova A. N. 2011. Logistics. Integration and optimization logisticheskix business-processes in the process. Moscow. (in Russian).

11. Karpova, N. P., Toimentseva, I. A., \& Haitbaev, V. A. (2019). Strategic Development of Enterprises in the Freight Services Market. In International Scientific Conference" Far East Con(ISCFEC 2018). Atlantis Press. https://dx.doi.org/10.2991/iscfec-18.2019.49 (in Russian).

12. McKinnon, A. (2019). Freight transport and logistics. In A Research Agenda for Transport Policy. Edward Elgar Publishing.

13. Navarro, P., Cronemyr, P., \& Huge-Brodin, M. (2018). How to implement green logistics: Using improvement processes for increasing environmental initiatives in freight transport companies. In 21st International Conference in Excellence in Services.

14. Tavasszy, L. (2019). Predicting the effects of logistics innovations on freight systems: directions for research. Transport Policy.

\section{Список литературы:}

1. Борисов Д. А. Внешняя политика Узбекистана при Ш. Мирзиёеве: стратегия и практика // Известия Уральского федерального университета. Серия 3: общественные науки 2019. T. 14 №2(188) C. 130-139. 
2. Камильджанов Б. И., Саматов Г. А., Галимова Ф. Р. Интеграция задач логистики важнейший инструмент стратегического управления // Информатика: проблемы, методология, технологии: материалы XV международной научно-методической конференции. 2015. Т. 2. С. 422-427.

3. Альбеков А. У., Эльдарханов Х.-М. Ю. Логистика. Ростов-на-Дону. 2009. 387 с.

4. Третьякова А. П., Зыков О. А. Логистика. Тюмень, 2010. 238 с.

5. Гаджинский А. М. Логистика. М.: Дашков и К 2012.484 с.

6. Левкин Г. Г. Логистика: теория и практика. Ростов н/Д: Феникс, 2009. 221 с.

7. Миротин Л. Б. Транспортная логистика. М.: Экзамен, 2002. 512 с.

8. Лукинский В. С. Модели и методы теории логистики. 2008. СПб.: Питер. 448 с.

9. Лавриков И. Н., Пеньшин Н. В. Транспортная логистика. Тамбов: ТГТУ, 2016. 90 с.

10. Дыбская В. В., Зайцев Е. И., Сергеев В. И., Стерлигова А. Н. Логистика. Интеграция и оптимизация логистических бизнес-процессов в цепях поставок. М.: Эксмо, 2014.

11. Karpova N. P., Toimentseva I. A., Haitbaev V. A. Strategic Development of Enterprises in the Freight Services Market // International Scientific Conference" Far East Con"(ISCFEC 2018). Atlantis Press, 2019. https://dx.doi.org/10.2991/iscfec-18.2019.49

12. McKinnon A. Freight transport and logistics //A Research Agenda for Transport Policy. Edward Elgar Publishing, 2019.

13. Navarro P., Cronemyr P., Huge-Brodin M. How to implement green logistics: Using improvement processes for increasing environmental initiatives in freight transport companies // 21st International Conference in Excellence in Services. 2018.

14. Tavasszy L. Predicting the effects of logistics innovations on freight systems: directions for research // Transport Policy. 2019.

Работа поступила

в редакиию 14.11.2019 2.
Принята к публикациии 19.11.2019 2.

Ссылка для циитирования:

Gaffarov M. Ways of Logistics Improvement of the Freight Market // Бюллетень науки и практики. 2019. Т. 5. №12. С. 312-315. https://doi.org/10.33619/2414-2948/49/36

Cite as $(A P A)$ :

Gaffarov, M. (2019). Ways of Logistics Improvement of the Freight Market. Bulletin of Science and Practice, 5(12), 312-315. https://doi.org/10.33619/2414-2948/49/36 